of a small central staff, nutritional surveys throughout the Colonial Empire. The Nyasaland party, which is being financed jointly by the Medical Research Council and the Colonial Development Fund, actually arrived in Nyasaland some months ago. An anthropologist under the auspices of the International Institute of African Languages and Cultures is working with the party. The party is now being joined by Dr. C. K. Ricardo and by Dr. E. Trewavas of the British Museum (Natural History), who will undertake a survey of the fishery resources of Lake Nyasa ; and also by Dr. G. A. C. Herklots, reader in biology to the University of Hong-Kong, who has been seconded for eight months to assist with the economic work. It is hoped that the surveys will produce valuable results, on one hand by increasing existing knowledge of the relation between nutrition and ill-health, and on the other hand by suggesting means whereby improvements in nutrition may be effected. It is also interesting to note that the present investigation in Nyasaland is the sort of scheme which Lord Hailey had in mind when advocating, in his recently published African Survey, that scientific research should form an essential basis of policy in Africa.

\section{New Broadcasting System}

AccordING to a recent report by the New York Correspondent of The Times, a new type of wireless transmission and reception will be used in an experimental station now being erected at Columbia University by Major E. H. Armstrong, professor of electrical engineering in the University, and inventor of the now well-known supersonic-heterodyne receiver. The station will use the frequency-modulation system of transmission, as distinct from the amplitudemodulation system at present used by all broadcasting stations. In the former method, the frequency of the emitted carrier wave is varied by the speech and music modulation; whereas in the methods so far employed, the frequency of the carrier wave remains constant and its amplitude is varied by the applied audio-frequencies. The principles of frequencymodulation have been known since the earliest days of radio-telephony, but it has remained for Prof. Armstrong to demonstrate how these may be brought into practical use with modern valves and circuit arrangements. Among the advantages claimed for the new system are that it effects a considerable reduction of interference in radio reception, and that a much larger number of broadcasting channels will become available in any given wave-length band. Against these, however, is the serious disadvantage that special receivers are necessary for frequencymodulated transmissions, and this factor is likely to involve serious delay in the introduction of the new system into modern broadcasting technique. The first transmitting station on the new system will be at Alpine, New Jersey, opposite New York City, and it has a licence to broadcast on a frequency of 40 megacycles per second (wave-length 7.5 metres). It is also understood that suitable receivers are already being manufactured, so that the result of this practical experiment will be awaited with interest.

\section{North Rona: A North Atlantic Island}

AT the Friday evening discourse at the Royal Institution on January 20, Dr. F. Fraser Darling described the island of North Rona. It is Britain's loneliest island; it lies forty-five miles north-west of Cape Wrath and north-east of the Butt of Lewis and is less than half a square mile in area. The island consists of Hebridean gneiss, but being free of peat and covered with a thin layer of soil, it differs radically from Lewis in its vegetative covering, which is of grass, quite free from heather. St. Ronan is reputed to be the first human inhabitant of Rona in the eighth century A.D. He built a cell almost underground, and much of the original building is still present. A chapel was built somewhat later contiguous with the cell and at its western end. Dr. and Mrs. Fraser Darling have excavated the accumulated stone and earth from the chapel and cell, disclosing the altar supports of masonry in the chapel, the rammed clay floor, the doorway into the cell, the original stone paving of the earlier building and the altar of masonry in the cell. Many quern stones and two fragments of stone vessels have been found. The wild life of Rona is of exceptional interest. There is an immense summer population of guillemots, razorbills, puffins, fulmar petrels, kittiwakes and great black-backed gulls. The storm petrel is also numerous, and Rona is one of the three British stations where Leach's fork-tailed petrel breeds. Rona is the headquarters of the Atlantic grey seal in Scottish waters, and a study of the social behaviour of this animal in the months it is ashore for breeding was the main purpose of Dr. Fraser Darling's expedition. Although this seal cannot dispense with the land for reproduction, this annual association with the land is a time of great danger. The social system is finely adapted to reducing the danger, and so are the animal's metabolic processes. The maiden cows and immature stock, for example, do not come ashore on the main mass of the island at the breeding season, but remain on skerries constantly ringed with surf. The calves feed from their mothers intensively for three weeks and are then weaned and left to find the sea for themselves. As the gestation period is $11 \frac{1}{2}$ months, mating takes place while the mothers are ashore with their calves.

\section{Royal Meteorological Society}

AT the annual general meeting of the Royal Meteorological Society held on January 18, Dr. B. A. Keen, the president, referred to the Council's activities in pressing for the installation of meteorological institutes in Great Britain, in order that urgently needed facilities, such as were available in many other countries, might be provided for research in meteorology in this country. The matter was also raised later in the evening, on the occasion of the award of the Buchan Prize to Dr. E. W. Hewson. Dr. Hewson, who is a Canadian and has recently been appointed to the Canadian Meteorological Service, was not able to be present to receive the prize, but in a letter which was read to the meeting he expressed his sense of indebtedness to the Beit Trustees and to the Royal Society of Canada for 